The general application of an inverse relation between degree of pigmentation and liability to cancer cannot be maintained, and it fails equally when applied to explain the varying incidence of the disease in different anatomical sites of the body. For carcinoma of the breast, the argument is much as follows. The woman of the white variety of mankind stands erect with her mammæ projecting, and fully exposed to direct solar irradiation; she has no pigment or hair to aid her delicate, translucent skin in protecting the glandular epithelium lying immediately beneath the surface. She covers her bosom with a single garmentthe flimsiest of white silk blouses. The man, in addition to wearing shirt and underclothing, protects his chest from irradiation by coat and waistcoat of dense cloth and of dark colour. Hence there are 100 cases of cancer of the breast in the woman to one in the man. The differences between the male and female, and between the mammary glands in the two sexes, are not of the subordinate importance assigned to them in determining the onset of cancer They are of primordial importance, since the difference between the male and female obtains for all species liable to carcinoma mammæ.

The frequency of this form of cancer in the woman requires to be considered, almost certainly, from totally different points of view. Not only do the sites of predilection vary from one class of vertebrate to another, but, if the Mammalia themselves be considered, some species are very liable to cancer of certain organs from which others, even nearly allied, are relatively or altogether exempt, as illustrated, e.g., by the variations in the frequency with which the mamma is attacked. The liability of the woman is merely a peculiarity shared, e.g., with the female of the mouse and dog, whereas in other domesticated mammals, e.g. in the cow, cancer of the mamma is practically unknown. Equal degrees of "irradiation" will not harmonise the parallel liability of the woman and the female wild mouse to cancer of the mamma, nor will differences in "irradiation" explain the exemption of the cow and the proneness of the tame albino and the wild grey mouse to this form of the disease.

These specific differences in liability depend in part, at any rate, on something more than external conditions. Under very divergent conditions, as regards habits (exposure to daylight), environment, and food, the incidence of cancer may be parallel, as in the case of the tame and wild mouse. Therefore innate fundamental tendencies of much biological import cannot be dismissed by assuming that cancer occurs in the mamma of dogs because the abdomen is "irradiated" through sitting up when " begging," or in consequence of a too great fondness for lying before an open fire. Nor can the biological significance of the sites of predilection for cancer of the rectum and uterus in mankind be explained by their corresponding with the sites on which a full bladder focusses actinic rays! The assumption that organs which are dark red or brown in colour are less liable to cancer than organs of a lighter colour will not explain why primary carcinoma of the liver is more frequently recorded in cattle than in othe: domesticated mammals.

A real and grave increase in cancer is asserted to have occurred during the past fifty years, and the attempts to allay tendencies to public panic by soothing assurances to the contrary are stated to be a praiseworthy policy, but intentionally misleading. This is rather a grave charge to bring, without substantiation, against investigators who have as much claim to be taken seriously as has Dr. Watkins-Pitchford in his explanation of the increase h alleges, viz. that there has been a decline in the use of woollen garments during the past fifty years, a change in the colour of the clothing worn, and that black broadcloth and black silk have ceased to be the clothing of respectable society, except the clergy, who enjoy a " privilege of cloth," and with it a low cancer death-rate.

In short, the prevention of cancer is represented as a matter of effective protection against solar irradiation, to which white man, having lost his pigmented skin, exposes himself both blindly and nakedly; but, we pause to ask, How is it, then, that the black-coated mouse is as liable to cancer as is the albino? We wonder if the difference in the recorded frequency of cancer in black and white man is the result of imperfart noportunities for observing the disease in the former, and of the attainment of the cancer-age by a smaller relative number of individuals. We remember that the black man and woman are by no means exempt from cancer, and we regret that the drudgery of putting their opinions to a sufficient test is not undertaken personally by a large army of arm-chair speculators who essay to write on the nature. cause, prevention, and cure of cancer. This punishment should certainly be theirs. E. F. B.

\section{CHEST DEVELOPMENT IN BOYS IN NEW SOUTH WALES.}

THE New South Wales branch of the British Science Guild has just circulated a report in which it states that a special sub-committee investigated a number of points in connection with the physical development of boys in New South Wales, and compared the results with those of other countries. It was found (I) that the average girth of English boys round the chest is roughly 3.6 inches more than that of boys in New South Wales at seventeen years of age; (2) Tasmanian boys have always measured rather more than New South Wales boys round the chest, and at the late age of sixteen or seventeen years they come approximately to the English average; (3) the chest growth of the New South Wales boy is at all ages much less than that of the Washington boy, viz. at nine years nearly I inch, at ten years more than I inch, between thirteen and fifteen years $I \frac{1}{2}$ inches or more; (4) as a result of this the lung capacity of New South Wales boys averages at all ages mucl less than that of the American boys, and the deficiency varies from 500 c.c. at nine years of age to 625 c.c. or more at seventeen years.

The committee found it difficult to give a complete estimate of the causes of this devitalising condition, the factors at its disposal being too indeterminate, but the suggestion is offered that the habit of the young Australian of leaning against lamp-posts and door-posts, or the difficulty with which he can be got to walk for an outing so long as there is a conveyance to be had, or his inveterate custom of supporting the games of cricket and football by leaning across a fence or resting his form upon a shaded bench while he bets upon the odds or barracks more or less enthusiastically, have to be considered in this connection.

The executive council of the Guild at Sydney passed the following recommendations:-(x) that the attention of the Government and municipal councils be drawn to the supreme importance of providing areas specially set apart and adapted for the purpose of healthy games, it being understood that such areas should be left bare of trees and flowers, save on borders, and should be provided with running tracks and facilities for cricket, football, lacrosse, basket-ball, and similar games; (2) that as the principle of taxing the unimproved value of land is a direct discouragement to schools to provide such areas, representation should accordingly be made to the Government and to municipal councils to allow some substantial concessions to all bona fide schools providing adequate playgrounds, such playgrounds being, like parks, really a guarantee of the peopie's health.

\section{THE ADMINISTRATION OF ANAESTHETICS.}

THE report recently presented to Parliament concerning deaths resulting from the administration of anæsthetics (Cd. 5III, price Id.) touches upon a matter of grave public interest, in which expert medical opinion and questions of pure science and the common sense of the intelligent "man in the street" alike contribute. We may say at once that the report appears to us to be of high value; it recognises a danger that for many years past has weighed very seriously upon the minds of those who know the danger, namely, of sudden death during the administration of chloroform, and it ends by recommending towards the remedy of this danger that a small standing committee or commission should be appointed to deal with the subject under the control of the Home Office.

The body of the report, although offering, no doubt, points open to criticism by individual authorities, is, on the

NO. 2 I I 4 , VOL. 83 ] 